\title{
Perlindungan Hukum Asuransi Pengguna Jalan Tol Oleh PT. Jasa Raharja Saat Mengalami Kecelakaan Lalu Lintas Pada Ruas Jalan Tol Jakarta-Cikampek
}

\author{
Edelweiss Ratna Fauziah ${ }^{1 *}$, Yetti Royati², Imanudin Affandi ${ }^{3}$ \\ Fakultas Hukum Universitas Singaperbangsa Karawang \\ J1. HS Ronggo Waluyo Kecamatan Telukjambe Timur Kabupaten Karawang \\ *Correspondence email: fzdelweiss@gmail.com, yettiroyati@gmail.com, iman_aff@yahoo.com
}

\begin{abstract}
Abstrak. Asuransi berasal dari kata vezekering yang artinya adalah pertanggungan. Orang yang ditanggung disebut vezekerde dan perusahaan asuransi disebut verzekeraar. Pada awalnya, asuransi memiliki untuk mengelola, mengalihkan atau membagi resiko, seiring dengan perkembangan ekonomi dan perkembangan pembangunan terhadap berbagai sektor pada bidang industri, ekonomi, infrastruktur maupun teknologi sehingga menyebabkan semakin banyaknya permasalahan yang terjadi, terutama permasalahan mengenai perlindungan hukum bagi masyarakat, seiring dengan perkembangan di bidang pembangunan infrastruktur misalnya dalam pembangunan jalan tol sehingga perlindungan hukum bagi pengguna jalan tol sangat di butuhkan. Asuransi sosial merupakan agunan sosial yang dibentuk oleh pemerintah indonesia berdasarkan peraturan Perundang-undangan, jika dipandang berdasarkan produk hukum asuransi sosial yang pernah diterbitkan di Indonesia dapat diketahui bahwa program asuransi sosial dikenal secara umum salah satunya adalah Asuransi Sosial Kecelakaan Penumpang yang saat ini lebih dikenal dengan Jasa Raharja. Dan untuk melaksanakan pertanggungan, pemerintah Indonesia menunjuk PT Asuransi Jasa Raharja untuk mengelola dan menyalurkan dana santunan kepada korban kecelakaan lalu lintas termasuk korban kecelakaan lalu lintas dalam ruas jalan tol Jakarta-Cikampek.
\end{abstract}

Kata kunci: Asuransi sosial, Jalan tol, Jasa Raharja

Abstract. Insurance comes from the word vezekering which means coverage. The person who is covered is called vezekerde and the insurance company is called verzekeraar. Initially, insurance has to manage, transfer or share risks, along with economic development and development developments in various sectors in the fields of industry, economy, infrastructure and technology, causing more problems to occur, especially problems regarding legal protection for the community, along with developments in the field of infrastructure development, for example in toll road construction, so that legal protection for toll road users is urgently needed. Social insurance is social insurance established by the Indonesian government based on statutory regulations, when viewed from the social insurance legal products that have been issued in Indonesia, it can be seen that social insurance programs are generally known, one of which is the Passenger Accident Social Insurance which is currently better known as Jasa Raharja. And to carry out coverage, the Indonesian government appointed PT Asuransi Jasa Raharja to manage and distribute compensation funds to traffic accident victims including traffic accident victims on the Jakarta-Cikampek toll road.

Keywords: Insurance, Highway, Jasa Raharja.

\section{PENDAHULUAN}

Pengangkuttan memiliki peran yang sangat pentng dan luas dalam pembangunan perekonomian di Indonesia. Pengangkutan dapat dilakukan dengan melalui beberapa jalur dinataranya dengan melalui jalur udara, darat dan laut baik untuk mengangkut barang ataupun orang. Dengan berkembang pesatnya perkembangan peradaban manusia khususnya dalam bidang teknologi dan trasportasi sehingga telah telah membawa manusia kedalam suatu sistem yang lebih maju dibandingkan pada saat zaman sebelumnya ${ }^{1}$

Peningkatan jumlah kendaraan khususnya angkutan penumpang maupun angkutan pribadi dari tahun ke tahun terus bertambah khususnya pada kendaraan roda empat, jumlah kendaraan yang terus bertambah tersebut berdampak kepada lalu lintas terutama di jalan alternatif. Dalam rangka meingkatkan kebutuhan ekonomi, pembangunan, menjaga kesinabungan pengembangan wilayah dan meningkatkan pelayanan jasa distribusi dengan itu pemerintah Indonesia melakukan pengembangan pembangunan infrastruktur termasuk pembangunan jaringan jalan tol, dikarenakan pembangunan jalan rol sangat dibutuhkan terutama pada daerah - daerah yang telah maju tinngkat perkembangannya yang bertujuan untuk menghindari timbulnya pemborossan, mengefisiensi waktu serta keamanan dan kenyamanan dalam perjalanan. Dengan dibangunnya jalan tol di beberapa derah di Indonesia sehingga masyarakat lebih memilih untuk menggunakan jalan tol utuk menghinndari kemacetan sebagai jalan yang dikenal bebas hambatan. Dengan meningkatnya pengguna jalan tol khususnya ruas jalan tol Jakarta-Cikampek tidak menutup kemungkinan sehinngga meningkatkan jumlah angka kecelakaan di ruas jalan tol tersebut.

${ }^{1}$ Sinta Uli,Pengangkutan : suatu tinjauan hukum multimoda trasport, angkutan laut, angkutan darat dan angkutan udara, USU Press, Medan,2006, hlm 1. 
Edelweiss Ratna Fauziah, Yetti Royati dan Imanudin Affandi, Perlindungan Hukum Asuransi Pengguna Jalan Tol Oleh PT. Jasa Raharja Saat Mengalami Kecelakaan Lalu Lintas Pada Ruas Jalan Tol Jakarta-Cikampek

Pada era globalisasi saat ini dengan berkembangnya teknologi, sarana transportasi menjadi kebutuhan yang utama bagi kehidupan masyarakat dalam menjalankan kegiatan sehari - hari terutama untuk memenuhi kepentingannya. Di sisi lain dalam kehidupan masyarakat adanya resiko tinggi terutama yang di sebabkan oleh kecelakaan yang di luar kesalahannya sehingga adanya kekhawatiran terhadap ketidak pastian sehingga menyebabkan meningkatnya kebutuhan masyarakat terhadap perlindungan melalui asuransi, saat ini terdapat banyak asurasi yang berkembang di indonesia yang di kelola oleh lembaga swasta ataupun pemerintah. Secara umum asuransi memang merupakan suatu cara untuk menangani ataupun mengantisipasi resiko - resiko dalam hidup seseorang. Asuransi terdiri dari berbagai macam diantaranya terdapat asuransi sosial, asuransi jiwa, asuransi kerugian dan asuransi varia yang diatur dalam berbagai Undang - undang yang berlaku².

Kebutuhan masyarakat Indonesia terhadap perlindungan ataupun resiko yang mungkin akan terjadi selalu berbeda, tergantung bagaimana kondisi yang sedang terjadi di masyarakat. Pada kenyataannya, asuransi sosial merupakan suatu kenyataan yang relatif muda di Indonesia. Bermula pada pertumbuhan dan perkembangan yang dilandaskan atas kebutuhan di masyarakat terhadap suatu jaminan sosial yang lebih terjamin. Di negara lain, untuk memberikan jaminan sosial kepada rakyatnya mulai dikembangkan pola asuransi sosial yang dimana pada dasarnya bertujuan untuk memberikan perlindungan hukum terhadap semua kemungkinan ataupun kerugian yang akan terjadi diluar kemampuan seseorang.

Asuransi pada umumnya terjadi didasari atas adanya kata sepakat oleh kedua belah pihak, yaitu tertanngung dan penanggung. Menurut Mehr dan Cammack asuransi merupakan alat untuk mengurangi resiko keuangan dengan cara menggabungkan sejumlah unit - unit yang beresiko agar kerugian individu secara kolektif dapat diprediksi. Kerugian yang dapat di prediksi tersebut kemudian dibagi dan di distribusikan secara proposional diantara semua unit - unit dalam penggabungan tersebut ${ }^{3}$. Peraturan asuransi harus mengacu dalam ketentuan Undang - undang, berdasarkan di dalam Undang - undang menjelaskan bahwa Asuransi adalah perjanjian dua pihak, yaitu perusahaan asuransi dan pemegang polis yang menjadi dasar bagi penerimaan premi oleh Perusahaan Asuransi sebagai imbalan untuk :

a. Memberikan penggantian kepada tertanggung dikarenakan kerugian, kerusakan, biaya yang timbul, kehilangan keuntungan atau tanggung jawab hukum kepada pihak ketiga yang mungkin diderita tertanggung karena terjadinya suatu peristiwa yang tidak pasti;

b. Memberikan pembayaran didasarkan pada meniggalnya tertanggung atau pembayaran yang didasarkan terhadap hidupnya tertanggung dengan yang besar telah di tetapkan dan/atau didasarkan pada hasil pengelolaan dana ${ }^{4}$.

Asuransi sosial merupakan jaminan sosial yang dibentuk pemerintah berdasarkan Undang - undang yang berlaku. Asuransi sosial adalah suatu mekanisme pengumpulan dan yang bersifat wajib dimana berasal dari iuran guna memberikan perlindungan atas risiko sosial ekonomi yang menimpa peserta atau keluarganya. Terdapat banyak jenis asuransi sosial di indonesia, salah satunya adalah Asuransi Sosial Kecelakaan Lalu Lintas Jalan dengan regulasi berpa Undang - undang Nomor 34 Tahun 1964 Tentang Dana Kecelakaan Lalu Lintas Jalan dan Peraturan Pemerintah Nomor 18 Tahun $1977^{5}$. Apabila dilihat dari produk hukumnya asuransi sosial pertamakali yang dikenal adalah Asuransi Sosial Kecelakaan Penumpang yang saat ini lebih dikenal dengan Jasa Raharja. Dalam melaksanakan pertanggungan tersebut, PT Asuransi Jasa Raharja di tunjuk oleh pemerintah untuk mengelola dan menyalurkan dana santunan kepada korban kecelakaan lalu lintas termasuk korban kecelakaan lalu lintas jalan ruas jalan tol Jakarta Cikampek.

Dalam hukum asuransi evenemen adalah dimana peristiwa yang tidak pasti yang menjadi beban penanggung, yang dimana apabila kecelakaan lalu lintas jalan iterjadi dan mengakibatkan timbulnya kerugian apabila pihak ketiga ataupun pihak yang bersangkutan mengalami kematian atau cacat tetap ataupun cedera. Dan PT Asuransi Jasa Raharja sebagai penanggung wajib mengganti kerugian pihak ketiga tersebut yang berada diluar angkutan lalu lintas.

PT Jasa Raharja berorientasi pada perasuransian namun memiliki konteks yang berbeda dengan asuransi lain, dikarenakan jasa raharja berlindung di balik kekuasaan negara dan selaku Badan Usaha Milik Negara, maka dengan itu cara pemupukan sumber dananya jelas, begitupun dengan penyalurannya. Dengan itu PT Jasa Raharja menggali polis dari sumbangan dan iuran wajib dari pemilik ataupun pengusaha angkutan lalu lintas jalan dan angkutan umum, sedangkan asuransi lainnya melalui polis yang dipasarkan kepada masyarakat. Fungsi utama dan tugas pokok dari PT Jasa Raharja adalah menghimpun dana dari masyarakat dengan cara mengadakan iuran wajib yang dipungut dari penumpang umum dan iuran tersebut diambil dari setiap penumpang yang sah dari kendaraan bermotor saja, maka dari itu dalam perkembangannya pemerintah melalui PT Jasa Raharja sebagai alat untuk melakukan tugas dan tanggung jawab sosial yang bertujuan untuk menghimpun, memupuk dan menyalurkan dana santunan jasa raharja

\footnotetext{
2 Tuti Rastuti, Aspek Hukum Perjanjian Asuransi, (Yogyakarta : 2011, Pustaka Yustitia), hlm 15.

${ }^{3}$ Mulhadi,SH.,M.Hum, Dasar - dasar Hukum Asuransi, (Depok : Rajawali Pers,2020), hlm 4.

${ }^{4}$ https://www.ojk.go.id/Files/201506/1UU402014Perasuransian_1433758676.pdf, Diakses tanggal 21/11/2020

${ }^{5}$ Mulhadi, Dasar - dasar Hukum Asuransi. (Depok : Rajawali Pers,2020) Hlm. 254.
} 
Edelweiss Ratna Fauziah, Yetti Royati dan Imanudin Affandi, Perlindungan Hukum Asuransi Pengguna Jalan Tol Oleh PT. Jasa Raharja Saat Mengalami Kecelakaan Lalu Lintas Pada Ruas Jalan Tol Jakarta-Cikampek

sebagai jaminan pertanggungan kepada korban atau ahli waris yang menjadi korban kecelakaan lalu lintas jalan.

Maka dapat disimpulkan bahwa asuransi sosial adalah salah satu perwujudan penyelenggaraan jaminan sosial yang berarti asuransi sosial itu benar - benar bermaksud dan bertujuan untuk memberikan suatu jaminan terhadap segala kemampuan masyarakat, karena kemungkinan kerugian itu disebabkan oleh hal - hal yang diluar kemampuan seseorang serta tidak bisa ditanggulangi sendiri maka dengan itu melalui PT Jasa Raharja yang dimana mengakomodir tentang perlindungan asuransi sosial bagi korban kecelakaan di jalan tol termasuk ruas jalan tol Jakarta - Cikampek.

\section{METODE}

Metodologi penelitian yang digunakan dalam penulisan hukum ini adalah pendekatan dengan menggunakan metode yuridis empiris dimana metode pendekatan yuridis empiris adalah suatu pendekatan masalah dengan cara meninjau peraturan - peraturan yang telah diberlakukan dalam masyarakat sebagai hukum positif dengan pelaksanaannnya termasuk dalam implementasi di lapangan.

\section{HASIL DAN PEMBAHASAN}

\section{Upaya Hukum Bagi Pengguna Jalan Tol PT Jasa Marga yang Mengalami Kecelakaan Lalu Lintas Untuk Mencairkan Asuransi Berdasarkan Permenhub}

Jaminan perlindungan bagi setiap warna negara oleh pemerintah, jaminan terhadap keselamatan penumpang dan pengguna kendaraan bermotor oleh asuransi. Di indonesia, jaminan terhadap keselamatan penumpang untuk ditanggung oleh asuransi jasa raharja. Premi atau santunan asuransi jasa raharja ditentukan sepihak oleh penumpang premmi dipungut melalui iuran wajib ditambahkan kepada harga tiket penumpang dari iuran sumbangan ditambah ketika membayara pajak Surat Tanda Nomor Kendaraan (STNK) setiap tahunnya. Premi yang di pungut selanjutnya di setorkan kepada penanngung yaitu PT Jasa Raharja.

Dasar berlakunya asuransi sosial kecelakaan lalu lintas jalan diatur dalam Undang - undang Nomor 34 Tahun 1964 beserta peraturan pelaksanaannya. Asuransi sosial merupakan asuransi yang di wajibkan oleh pemerintah dikarenakan bukan berdasarkan perjanjian tetapi berlakunya asuransi sosial kecelakaan lalu litas jalan didasari oleh Undang - undang. Pemerintah Indonesia sebagai pihak penyelenggara asuransi tersebut mendelegasikan kepada Badan Usaha Milik Negara PT Jasa Raharja. Terdapat beberapa pihak yang terlibat dalam asuransi kecelakaan lalu lintas jalan, diantaranya : Pihak pemilik/pengusaha kendaraan bermotor, yang dapat menjadi penyebab kecelakaan lalu lintas jalan dan pihak penguasa dana, yaitu pemerintah yang di delegasikan kepada Badann Usaha Milik Negara.

Asuransi Sosial Kecelakaan Lalu Lintas Jalan meiliki tujuan untuk melindungi masyarakat dimana dananya dihimpun dari masyarakat dan digunakan untuk kepentingan masyarakat itu sendiri yang diancam oleh bahaya lalu lintas jalan termasuk bagi pengguna jalan tol. Dana yang telah terkumpul dari masyakarat tetapi belum digunakan untuk dana kecelakaan lalu lintas jalan akan dimanfaatkan untuk kesejahteraan masyarakat melalui investasi berdasarkan Undang - undang Nomor 34 Tahun 1964.

Perusahaan Negara Asuransi Kerugian Jasa Raharja sebagai perusahaan negara yang berubah bentuk hukum menjadi Badan Usaha Milik Negara PT Asuransi Kerugian Jasa Raharja sebagai perusahaan yang ditunjuk untuk mengurus dana kecelakaan lalu lintas jalan yang di tunjuk oleh menteri keuangan khusus. Perusahaan negara yang dimaksud adalah Perusahaan Negara Asuransi Kerugian Jasa Raharja yang merubah bentuk hukum menjadi Badan Usaha Milik Negara PT Asuransi Kerugian Jasa Raharja, dimana kedudukan PT Asuransi Jasa Raharja dalam Asuransi Kecelakaan Lalu Lintas Jalan sebagai penanggung. Akan tetapi dalam pasal 13 Peraturan Pemerintah Nomor 18 Tahun 1965 mengatur bahwa ancaman bahaya kecelakaan lalu lintas jalan yang menjadi beban penanggung itu tidak da sehingga untuk pembayaran dana pada korban juga tidak ada seperti bunuh diri, percobaan bunuh diri, atau suatu kesengajaan lain pada pihak korban atau ahli warisnya , kecelakaan yang terjadi pada saat korban sedang mabuk atau tidak sadar, melakukan perbuatan kejahatan, atau kecelakaan yang terjadi tidak langsung disebabkan oleh pengguna kendaraan bermotor dan kereta api yang bersangkutan dengan fungsinya sebagai alat angkutann lalu lintas jalan, misalnya digunakan dalam perlombaan kecepatan, karena huru hara, kerusuhan, pemogokan dan sebagainya.

PT Asuransi Jasa Raharja masuk ke dalam golongan asuransi kerugian dikarenakan pembayaran iuran wajib bersamaan ketika pembayaran pajak kendaraan bermotor yang sering disebut juga dengan sumbangan wajib jasa raharja dan apabila penumpang angkutan umum pembayaran iuran wajib bersamaan dengan ketika pembelian tiket penumpang sebagai pertanggungan. Besarnya jumlah dana dalam hal kematian atau cacat tetap, penggantian maksimum biaya - biaya pengobatan dokter, serta biaya penguburan ditentukan oleh Menteri Keuangan berdasarkan pasal 11 Peraturan Pemerintah Nomor 18 Tahun 1965. Peraturan Pemerintah Nomor 18 Tahun 1965 mengatur tentang setiap orang yang berada diluar alat angkutan lalu lintas jalan yang menjadi korban dari akibat kecelakaan lalu lintas jalan diberi hak atas pembayaran dana kecelakaan lalu lintas jalan. Pembayaran dana kecelakaan lalu lintas jalan diberikan dalam hal - hal berikut ini :

1. Bagi korban meninggal dunia dalam waktu 365 hari setelah terjadinya kecelakaan;

2. Untuk korban mendapat cacat tetap dalam waktu 365 hari setelah terjadi kecelakaan; 
Edelweiss Ratna Fauziah, Yetti Royati dan Imanudin Affandi, Perlindungan Hukum Asuransi Pengguna Jalan Tol Oleh PT. Jasa Raharja Saat Mengalami Kecelakaan Lalu Lintas Pada Ruas Jalan Tol Jakarta-Cikampek

3. Untuk biaya - biaya perawatan dan pengobatan dokter yang dikeluarkan dari hari pertama setelah kecelakaan dalam waktu paling lama 365 hari;

4. Bagi korban meninggal tidak mempunyai ahli waris kepada pihak yang melakukan penguburannya maka akan diberikan pergantian biaya penguburan;

5. Pembayaran untuk dana penggantian biaya - biaya perawatan dan pengobatan dokter tersebut adalah sebagai tambahan dan tidak dikurangkan dari pembayaran dana untuk kematian atau cacat tetap yang dimaksudkan diatas. Dalam korban tidak meninggal dunia, pembayaran dana diberikan kepada korban itu sendiri sedangkan bagi korban meninggal dunia, yang berhak untuk menerima dana ialah :

a. Janda/dudanya yang sah;

b. Jika janda/dudanya tidak ada maka anak - anaknya yang sah;

c. Jika anak - anaknya tidak ada maka orang tuanya yang sah.

Tuntutan ganti kerugian pembayaran dana diajukan kepada penanggung, yaitu PT Asuransi Kerugian Jasa Raharja sebagai penguasa dana. Berdasarkan pasal 17 Peraturan Pemerintah Nomor 18 Tahun 1965 menentukan pembuktian keabsahan suatu tuntutan pembayaran dana wajib diserahkan surat - surat serta bukti bagi korban meninggal dunia, proses verbal polisi lalu lintas atau lain yang berwenang, keputusan hakim atau pihak berwajib lain yang berwenang tentang pewarisan yang bersangkutan, bukti serta surat keterangan dokter guna pengesahan fakta kematian yang terjadi. Untuk korban cacat tetap atau cedera, proses verbal polisi lalu lintas atau lain yang berwenang, surat keterangan dokter tentang jenis cacat tetap/cedera yang telah terjadi akibat kecelakaan lalu lintas yang bersangkutan dan surat bukti lain yang dianggap penting guna pengesahan fakta cacat tetap/cedera yang terjadi. Adapun cara untuk memperoleh dana santunan yang telah disediakan oleh PT. Asuransi Kerugian Jasa Raharja $(\text { Persero })^{6}$ :

1. Formulir model K1 untuk kecelakaan ditabrak kendaraan bermotor yang dapat di peroleh di Polres dan Kantor Jasa Raharja terdekat;

2. Formulir K2 untuk kecelakaan penumpang umum dapat di peroleh di Kepolisian/Perumka/Syahbandar laut/Bandar Udara dan Kantor Jasa Raharja Terdekat. Adapun cara pengisian formulir adalah sebagai berikut :

a. Keterangan identitas korban/ahli waris diisi oleh yang mengajukan dana santunan;

b. Keterangan kecelakaan lalu lintas diisi dan disahkan oleh Kepolisian atau pihak yang berwenang lainnya;

c. Keterangan kesehatan/keadaan korban diisi dan di sahkan rumah sakit atau dokter yang merawat korban;

d. Apabila korban meninnggal dunia, tentang keabsahan ahli waris, diisi dan disahkan oleh pamong praja/lurah/camat.

e. Bukti yang diperlukan apabila korban menderita luka - luka untuk mendapatkan santunan maka diperlukan kuitansi biaya perawatan dan pengobatan yang asli serta dengan identitas korban.

Hak santunan Jasa Raharja menjadi gugur atau kadaluarsa apabila permintaan diajukan dalam waktu lebih dari enam bulan setelah hak yang dimaksud di setujui oleh jasa raharja. Setelah pembayaran dana dilakukan maka PT Asuransi Kerugian Jasa Raharja tidak memiliki kewajiban apapun untuk melakukan suatu pembayaran berikutnya berdasarkan Pasal 18 Ayat 3 Peraturan Pemerintah Nomor 18 Tahun 1965. Akan tetapi apabila Direksi PT Asuransi Kerugian Jasa Raharja telah memperoleh keyakinan tentang keabsahan tuntutan lain, pembayaran dana dapat dilakukan berdasarkan surat - surat atau bukti/kenyataan - kenyataan lain.

\section{Perlindungan Hukum Terhadap Pengguna Jalan Tol Berdasarkan Undang - Undang Nomor 8 Tahun 1999}

Perlindungan hukum sangat dibutuhkan dikalangan masyarakat dimana disaat masyarakat merasa dirugikan oleh produk yang dikonsumsinya. Hal itulah menjadi salah satu alasan masyarakat menuntut ganti kerugian kepada pelaku usaha, akan tetapi pada kenyataannya masyarakat tersebut belum mendapatkan perlindungan hukum yang tepat dikarenakan masih lemahnya perlindungan hukum yang dibuat pemerintah untuk masyarakat yang dirugikan.

Untuk mewujudkan perlindungan hukum terhadap hak - hak khususnya bagi pengguna jalan tol termasuk pengguna jalan tol ruas Jakarta - Cikampek maka dari itu Badan Pengatur Jalan Tol sebagai regulator jalan tol memberikan syarat bagi pengusaha jalan tol untuk memberikan pelayanan yang maksimal sebagai kontraprestasi pembayaran jalan tol terhadap penggunanya, maka dari itulah ditentukan melalui Standar Operasional Prosedur internal PT Jasa Marga agar dapat memberikan perlindungan terhadap pengguna jalan tol. Jalan tol merupakan jalan yang dikhususkan untuk kendaraan roda empat atau lebih yang bertujuan untuk mempersingkat jarak dan waktu tempuh dari satu tempat ke tempat lainnya sedangkan berdasarkan Peraturan Pemerintah Nomor 15 Tahun 2005 Tentang Jalan Tol menjelaskan bahwa jalan tol merupakan jalan umum yang merupakan dari bagian sistem jaringan jalan dan sebagai jalan nasional yang penggunanya diwajibkan membayar tol. Jalan tol harus memiliki spesifikasi

${ }^{6}$ Herman Darmawi,Manajemen Asuransi,(Jakarta : Bumi Aksara, 2000). Hlm. 169 - 170 
yang baik yaitu dimana pada disetiap jalan tol harus tersedia sarana deteksi keamanan dan sarana komunikasi yang memungkinkan pertolongan apabila terjadinya kecelakaan dan bagi jalan tol antarkota harus terdapat tempat istirahat dan pelayanan untuk kepentingan pengguna jalan tol dan tempat istirahat tersebut setidaknya disediakan paling sedikit satu untuk setiap jarak 50 kilometer pada setiap jurusan berdasarkan Pasal 7 Peraturan Pemerintah Nomor 15 Tahun 2005 Tentang Jalan Tol. Dalam Pasal 87 dan Pasal 88 Peraturan Pemerintah Nomor 15 Tahun 2005 Tentang Jalan Tol mengatur tentang hak - hak yang dimiliki oleh pengguna jalan tol yaitu bahwa pengguna jalan tol berhak menuntut ganti rugi kepada Badan Usaha atas kerugiakan yang disebabkan dari Badan Usaha dalam Pengusahaan jalan tol serta berhak mendapatkan pelayanan jalan tol yang sesuai dengan standar pelayanan minimal tol.

Ada bebagai macam permasalahan yang sering di hadapi oleh pengguna jalan tol diantaranya tidak mendapatkan informasi yang jelas mengenai keadaan jalan tol dan menimbulkan kerugian akibat terjebak banjir, kemudian tentang pemberitahuan layanan derek mobil gratis di jalan tol namun pada kenyataannya pengguna jalan tol masih dipungut biaya atas jasa derek tersebut kemudian kasus pemberlakuan $e$-money sebagai alat transaksi jalan tol yang masih dinilai kurang cocok dan masih dipertanyakan jaminan keamanan saldo para pengguna jalan tol.

\title{
SIMPULAN
}

Berdasarkan ketentuan pasal 5 Undang - undang Nomor 34 Tahun 1964 bahwa pengurusan dan penguasaan dana dilakukan oleh Perusahaan Negara yang ditunjuk menteri keuangan khusus dan perusahaan negara yang dimaksud itu adalah Badan Usaha Milik Negara PT Asuransi Kerugian Jasa Raharja dan perusahaan tersebut juga mengurus dan menguasai dana kecelakaan lalu lintas jalan, selain itu PT Asuransi Jasa Raharja memilliki kedudukan sebagai penanggung. Besarnya jumlah dana korban kecelakaan lalu lintas jalan termasuk untuk korban kecelakaan jalan tol ruas Jakarta-Cikampek dalam hal kematian atau cacat tetap, dan penggantian maksimum biaya - biaya pengobatan dokter, serta biaya penguburan ditentukan oleh Menteri Keuangan berdasarkan Pasal 11 Peraturan Pemerintah Nomor 18 Tahun 1965. Setiap orang yang berada diluar alat angkutan lalu lintas jalan, yang menjadi korban akibat kecelakaan lalu lintas jalan diberi hak atas pembayaran dana kecelakaan lalu lintas jalan. Pembayaran untuk dana penggantian biaya - biaya perawatan dan pengobatan dokter tersebut adalah sebagai tambahan dan tidak dikurangkan dari pembayaran dana untuk kematian atau cacat tetap. Bagi korban tidak meninggal dunia, pembayaran dana diberikan kepada korban sendiri. Akan tetapi, dalam hal korban meninggal dunia, maka yang berhak menerima pembayaran dana adalah ahli waris. Untuk pembuktian keabsahan suatu tuntutan pembayaran dana wajib disserahkan surat - surat bukti yang di tentukan oleh pasal 17 Peraturan Pemerintah Nomor 18 Tahun 1965.

\section{DAFTAR PUSTAKA}

\section{Buku}

Akhmad.Nova Gamayanti Putri. Perlindungan Hukum Bagi Pengguna Layanan Jalan Tol Oleh Pt. Jasa Marga (Persero) Tbk Di Jakarta. Skripsi. Program Sarjana Fakultas Hukum Universitas Universitas Islam Indonesia. Yogyakarta : 2018

Mulhadi, SH. M.Hum. Dasar - dasar hukum asuransi. Depok : Rajawali Pers, 2020

Prof. Abdulkadir Muhammad, SH. Hukum Asuransi Indonesia. Bandung : PT Citra Aditya Bakti,2011

\section{Peraturan Perundang-Undangan}

Indonesia, Undang - Undang Republik Indonesia Nomo 38 Tahun 2004 Tentang Jalan

Indonesia, Undang-Undang Republik Indonesia Nomor 40 Tahun 2014 Tentang Perasuransian

Indonesia, Peraturan Pemerintah No. 15 Tahun 2005 Tentang Jalan Tol

\author{
Naskah Internet \\ Jasa Marga. "Profil Perusahaan". http://jasamarga.com/public/id/infoperusahaan ./ProfilPerusahaan/Overview.aspx \\ Diakses tanggal 21/11/2020 \\ Otoritas Jasa Keuangan. "Perasuransian" https://www.ojk.go.id/Files/.201506/1UU402014 \\ Perasuransian 1433758676.pdf . Diakses tanggal .21/11/2020
}

